\title{
Spaces and species: The Rodrigo Botet Collection (Valencia, Spain) and the palaeoecological relationships of early Homo sapiens during their dispersal in the southern cone of South America
}

\author{
Karina V. CHICHKOYAN ${ }^{*}$, Margarita BELINCHÓN ${ }^{2}$, José L. LANATA \& Bienvenido \\ MARTÍNEZ-NAVARRO ${ }^{1,4}$
}

${ }^{1}$ IPHES, Institut Català de Paleoecologia Humana i Evolució Social, Zona Educacional, 4. Campus Sescelades URV (Edifici W3) 43700 Tarragona, Spain. Area de Prehistoria, Universitat Rovira i Virgili (URV). Avinguda de Catalunya 35, 43002 Tarragona, Spain; karinavch@gmail.com

${ }^{2}$ Museo de Ciencias Naturales de Valencia, Spain. General Elio s/n, 46010, Valencia, Spain; museociencias@valencia.es

${ }^{3}$ IIDyPCa, Instituto de Investigaciones en Diversidad Cultural y Procesos de Cambio. CONICET. Mitre 630, 8400, Bariloche, Argentina; jllanata@conicet.gov.ar

${ }^{4}$ ICREA, Barcelona, Spain; bienvenido.martinez@icrea.cat

* Corresponding author

Chichkoyan, K.V., Belinchón, M., Lanata, J.L. \& Martínez-Navarro, B. 2015. Spaces and species: The Rodrigo Botet Collection (Valencia, Spain) and the palaeoecological relationships of early Homo sapiens during their dispersal in the southern cone of South America. [Espacios y especies: la colección Rodrigo Botet (Valencia, España) y las relaciones paleoecológicas de Homo sapiens durante su dispersión inicial en el cono sur Sudamericano]. Spanish Journal of Palaeontology, 30 (1), $15-32$.

\begin{abstract}
In this paper we present the taphonomic analysis of the Rodrigo Botet Collection, an assembly of fossil bones excavated from the Region of the Pampas (Argentina) which display evidence of having been subject to anthropic action. This collection of South American mammals is housed at the Natural Science Museum of Valencia (Spain), and is the most important of its type in Europe. In order to better comprehend the evidence found in this collection a palaeoecological framework was applied. This framework was linked to the relations established between Homo sapiens and the native megafauna, which may have implied new forms of niche construction or colonization in South American spaces. The distribution of the different species over the landscape, the general ecological characteristics of these mammals, and the presence of possible competitors were taken into account
\end{abstract}

RESUMEN

En este trabajo se presenta el análisis tafonómico realizado en la Colección Rodrigo Botet, proveniente de la Región Pampeana (Argentina) donde se hallaron distintos huesos con evidencias de intervención antrópica. Esta colección de mamíferos Sudamericanos se encuentra alojada en el Museo de Ciencias Naturales de Valencia (España) y es la más importante de este tipo en Europa. Un marco paleoecológico fue aplicado a fin de entender la evidencia encontrada. Este se vinculó con las relaciones que Homo sapiens estableció con la megafauna nativa y que pudo significar la construcción y/o colonización de nichos en los espacios sudamericanos. Para analizar esta dinámica se tuvo en cuenta la distribución de las diferentes especies en el paisaje, las características ecológicas de estos mamíferos y la posible presencia de competidores. En este contexto, las poblaciones humanas se 
during the research. In this context we emphasise that human beings behaved as an invasive species in this continent during the first peopling of America. Special attention is also placed on comparing different early human dispersal events in different scenarios. America and Europe are exemplary case studies for making further discoveries on the several anthropic impacts that our species has exerted in different times and spaces.

Keywords: American peopling, megafauna, PleistoceneHolocene Transition, Pampean Region, Argentina. habrían comportado como una especie invasora durante el primer poblamiento americano. También se hace un énfasis especial en la importancia de comparar distintas situaciones de dispersiones tempranas en distintos escenarios. En este sentido, América y Europa son excelentes casos de estudio para dar cuenta de los distintos tipos de impacto que nuestra especie realizó en diferentes espacios y tiempos.

Palabras clave: Poblamiento americano, megafauna, Transición Pleistoceno-Holoceno, Región Pampeana, Argentina.

\section{INTRODUCTION}

The dispersal of Homo sapiens in Eurasia and in America has been a challenge for researchers. In both continents, the entry of our species occurred in unique palaeoecological contexts: in Eurasia, there have been pulses of colonization by species of the genus Homo since at least the early Pleistocene. They introduced some environmental modifications and, in the last millennium, competed with Homo sapiens for the exploitation of resources. This was not the case in America, since Homo sapiens was the first and only Homo species that thrived in this continent during the late Pleistocene. Specifically, in South America, the human population found a unique assortment of animals, the South American megafauna, that had developed thanks to the relative isolation of the continent during part of the Cenozoic Era until 3 Ma ago (Webb, 1978; Fariña et al., 2013). In both continents, Eurasia and South America, geographical dispersal took place successfully which, as a result, affected the diversity in species and changed their native relationships. Specifically, this paper focuses on presenting how this happened in the Pampas, a nodal sector for the evolution of populations of megafauna and for the dispersal of Homo sapiens, since it joins the Brazilian and Guayanian regions and the southernmost part of the continent.

To further explore the matter, we studied the interaction between Homo sapiens and megafauna through a series of taphonomic analyses on the items in the Rodrigo Botet Collection at the Natural Science Museum of Valencia (Spain) (Chichkoyan, 2011, 2013; Chichkoyan et al., 2013). This collection is the most important of its kind in Europe and has been kept in Spain since the end of the 19 th century. Several fossil bones in this collection were detected to have been subject to human action. In order to analyse these results, a palaeoecological framework was applied. This approach allows for its interpretation from the general perspective of interaction. The resulting aggregate of species in the space, their ecological characteristics, like the fact that they had never before been in contact with humans or their sexual maturity and reproduction strategies and, also, the low interspecific competition among carnivores, might have favoured the creation of new paleoecological relationships, such as niche construction or colonization of those already existent. This could be related to the possible invasive nature (sensu Lanata et al., 2008a, b) of Homo sapiens during their first dispersal in the Americas, destabilizing in the process of its native trophic chain.

Firstly, we will offer an explanation of the general specifications of our materials and methods and, further on, of the fauna that displayed signs of anthropic action. The following section will describe the results of the analysis. The paper ends with the discussion and conclusions drawn from these findings, integrated into a general overview of the palaeoecological interactions between human beings and megafauna.

\section{MATERIALS AND METHODS}

The American Southern Cone is a relevant space for the comprehension of the palaeoecological relationships established by humans with other large mammal species. Although South America, especially the Southern Cone, offers plentiful evidence of the interaction between human beings and megafauna, this information is still relative poorly understood (Borrero, 2008, 2009) and has not been integrated to the new general dispersal models of human population for different environments.

The focus here will be placed on the Pampean Region, one of the richest in megamammals during the Pleistocene. The discovery of various mammalian skeletons in this area enabled the creation of a chronostratigraphic sequence for the entire continent (Cione et al., 2009). This region was characterized by an arid and dry weather, with a low vegetation strata and the predominance of open spaces. It is located between 31 degrees and 39 degrees South and is an ecotonal biotope located between two large biogeographical 
regions: the Brazilian Region to the North and the Patagonic Region to the South. Thus, it has always been influenced by the palaeoenvironmental changes of both regions (Rabassa et al., 2005; Ortiz-Jaureguizar \& Cladera, 2006; Gutiérrez \& Martínez, 2008; Cione et al., 2009).

South American megafaunal extinction is an issue of great relevance when dealing with these species of native fauna. However, even if it is the subject of an important academic debate, the issue will not be addressed in this paper, for our primary concern is merely to discuss human palaeoecological relationships established during the first peopling of America. A good overview of this debate can be found in Koch \& Barnosky (2006), and references therein. In this sense, it is necessary to go beyond the event of extinction itself and elucidate the human migration process through the territory during niche construction. This relates to the modifications that the organism caused in the environment, disturbing or changing the relationships between organisms and bringing about evolutionary change (Odling-Smee et al., 2003). As to further this line of investigation, it is necessary to incorporate archaeological information backed up by evidence provided by palaeoecology, in order to allows us to integrate historical, ecological, taphonomic and geological concepts for the better understanding of life in the past (Wing et al., 1992). Therefore the evidence provided by our research will merge with the palaeoecological characteristics of the native fauna and paleontological and palaeoecological concepts. It is useful to understand the relationships in the faunal population before the irruption of human beings, the expansion of a new species into a novel environment, its interaction with the native species, the influence that it could have exerted on the environment and how it overcame natural barriers (Harding et al., 2006). All these elements apply to the case of Homo sapiens in the New World, a Homo species with a more flexible capacity for adapting when compared to the last million years of its evolution (Surovell et al., 2005).

In order to further the research on the palaeoecological consequences that humans caused during their dispersal in the American environment, it is necessary not only to consider the information from excavations under stratigraphic control, but also, to gather information from collections housed in different museums. Even though they lack context, this kind of material may provide important information, for they may be analysed by means of new methodologies and theoretical frameworks (Pérez de Micou, 1998; Huster, 2013) and later integrated into different studies carried out in the region. This kind of analysis is fundamentally important to the study of general patterns of human behaviour in the past and their overall relation with the different palaeoregions on a large scale. This is one of the essential objectives of this work of palaeobiological and archaeological research that at the same time also allows interregional comparison (Stiner,
1994; Gamble, 2002). Consequently, the study of this material is a key element for the advancement of current investigations, not only because it minimizes the impact that a campaign of excavation has on the environment, by avoiding the destruction of the sites, but also because the material may be re-evaluated in new studies (Goetze \& Mills, 1991; Pérez de Micou, 1998; Pérez et al., 2005; Huster, 2013). In addition, it integrates material into ongoing research carried out in Argentina and the rest of South America but which is kept elsewhere.

These collections are composed of fossil elements that were extracted from non-stratigraphical excavations carried out during the 19th century, when different voyagers undertook journeys to both the Pampean and Patagonian regions (Chichkoyan, 2011). They are composed of different large mammals - over $44 \mathrm{~kg}$ in weight - and species of megafauna - over $1,000 \mathrm{~kg}$ - and most of them, have never been studied from this perspective, so they may prove an important source of information. Although these 19th century collections lack a precise stratigraphic context, it is possible to obtain chronologies from bones with evidence of human activity, providing reliable evidence and enabling the contextualisation of this interaction. This can be used to generate new research expectations and/or interpretative models that integrate both archaeological and palaeoecological information.

The taphonomic study carried out on the Rodrigo Botet Collection, is an exemplary case study and relevant to this subject (Chichkoyan, 2011, 2013; Chichkoyan et al., 2013). This is the most important collection of South American fossil megafauna in Europe and has been the subject of paleontological studies performed by Boscá y Casanoves, first curator of the collection (Boscá y Casanoves, 1899, 1902, 1917, 1919, 1921, 1923a, b; among others). It was donated to the Museum of Valencia by Rodrigo Botet at the end of the 19th Century and is the result of non-systematic excavations executed by Enrique de Carles in the northeastern sector of the Pampean Region: Samborombón Bay, and different zones near the rivers of La Plata, Salado, and Samborombón (Fig. 1). The collection is composed of 29 genera and 66 species, such as Smilodon, Mylodontidae, Glyptodonts, and Notoungulata, among others. It was part of the first Paleontological Museum in Europe and it is characterized by the quantity and diversity of material. It also includes important human remains, such as the "Samborombón skeleton", used by Ameghino to discuss when the first American peopling took place (Martel San Gil \& Aguirre Enríquez, 1964; Salinas Jaques, 2001; Catalá Gorges, 2004; Belinchón et al., 2009).

The bones of which this collection is composed were analysed by means of taphonomic methodologies. Studies on bone surfaces are useful not only to find and describe anthropic cut marks, but also to discover paleoenvironmental and ecological information (Behrensmeyer \& Kidwell, 1985; Bonnichsen, 1989; Bello \& Soglio, 2008). The 


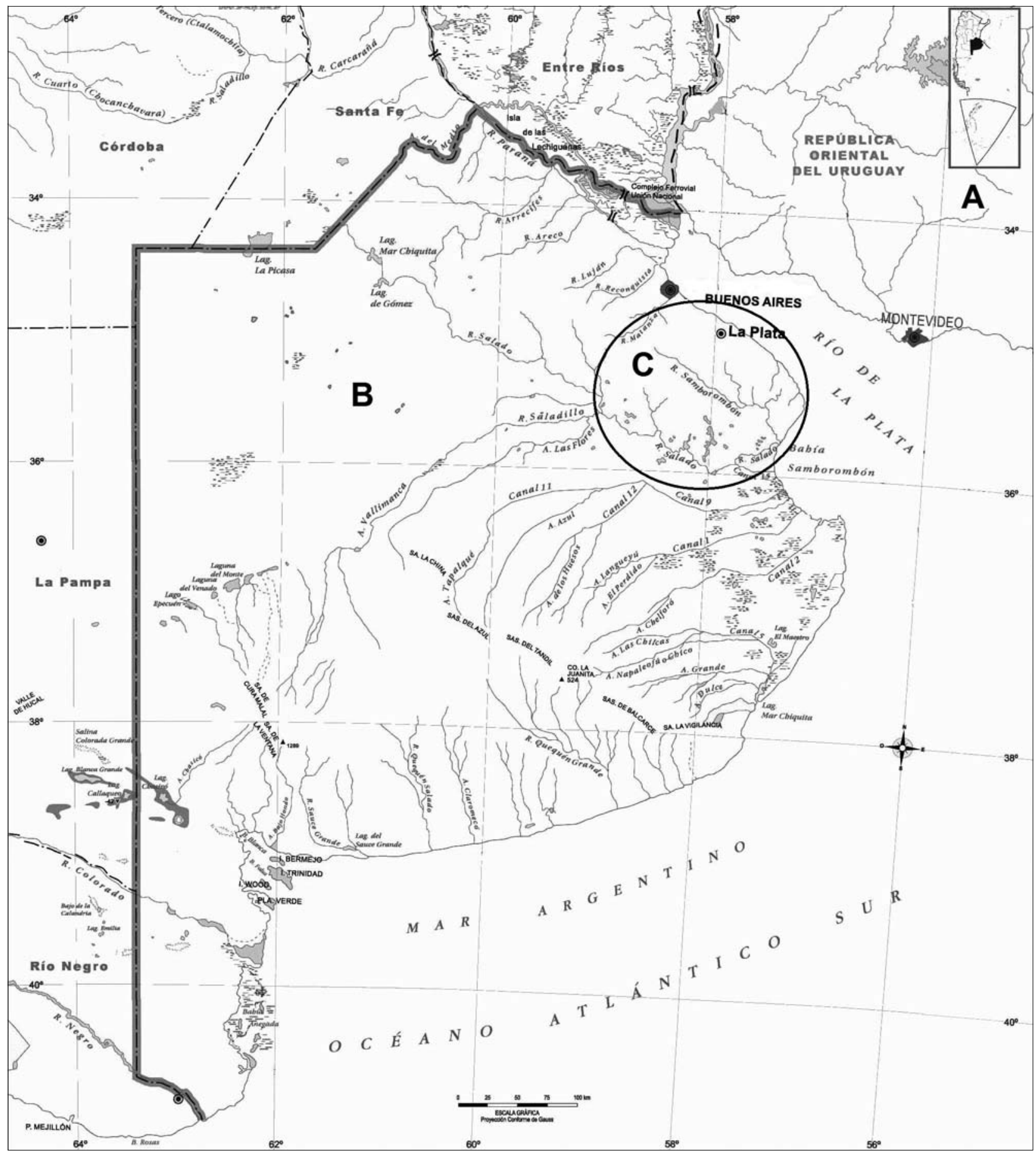

Figure 1. Geographical setting. A) Argentina. B) Buenos Aires Province. C) General provenance of the Rodrigo Botet Collection. (Modify from IGM).

traces left on bones can be linked to their causal agency and, in this way, can be used to determine the element that brought them about (Gifford-Gonzalez, 1991; Lyman, 1994). This can be put into practice not only in the case of human-made marks, but also for imprints that were caused by other natural elements (Binford, 1981; Behrensmeyer, 1991; Lyman, 1994; Coard, 1999; Fernández López,
2000; Domínguez-Rodrigo et al., 2009). Therefore, the taphonomic history of the bones housed in the museums, which lack any sedimentary context, may be interpreted.

For this work, 11,466 bones over $2 \mathrm{~cm}$ long, with their cortical surface in an adequate state of preservation were selected. Firstly, they were analysed with the aid of magnifying glasses and stereoscopic microscopes 
- Olympus SZ-PT - in order to differentiate any bone presenting human action from those affected by eroding agents such as carnivores, roots, weathering, trampling, wind or fluvial transport and any other natural factor (details in Chichkoyan, 2011). Currently, new studies and new methodologies are being applied on the material. It has been re-viewed with the aid of microscopes equipped with 6.4, 16 and 40X magnification lenses - Wild Heerbrugg $\mathrm{M} 3 \mathrm{~B}$-, and other processing methodologies will also be applied in the future in order to retrieve the maximum information possible from the sample or improve previous results derived from the collection.

However, the material will be presented in the same fashion as in previous works (Chichkoyan, 2011, 2013; Chichkoyan et al., 2013). Only bones that display signs of human intervention and have been assigned to a taxonomic group are presented in this study. Although other researchers describe and classify the cut marks (Walker \& Long, 1977; Abe et al., 2002; Bello \& Soglio, 2008; Bello et al., 2009; De Juana, 2010; among others) we considered that any bone that displayed V-shaped markings in areas consistent with the process of butchering, and which had occurred prior to any other type of post-depositional process, such as weathering, trampling, deterioration by the action of roots, manganese stains or other eroding factors like water or wind, would have been subject to anthropic action (Binford, 1981; Shipman, 1981; Lyman, 1994; Bunn, 1999; Fernández López, 2000; DomínguezRodrigo et al., 2009). Several elements of the collection that had been subject to human action could be the result of intentional patterns created as a result of anthropic polish. Markings were described in terms of orientation, general position on the bone, and their relative position with other marks derived from non-human activity, plus any other information considered relevant, not only of the mark itself but also of its surrounding context. This allowed for the understanding of the taphonomic history of the different bones with cut marks. In addition, the species on which these were found offers information on the ecological characteristics, chronology and distribution of these populations. The relative position of the markings on the bone grants insight on the general butchering process and stages of the animal's exploitation by human beings.

In the following section, the general characteristics of the species that have been subject to human intervention in the Rodrigo Botet Collection are described. And later on, the results of the analyses will be presented and discussed.

\section{SYSTEMATICS}

\author{
Phylum CHORDATA Bateson, 1885 \\ Class MAMMALIA Linnaeus, 1758 \\ Order XENARTHRA Cope, 1889 \\ Family Mylodontidae Gill, 1872
}

Mylodons (Fig. 2) are part of the Order Xenarthra, which originated in South America. This order is divided into Cingulata - an explanation will be offered later on and Pilosa, which is in turn divided into Vermilingua or anteaters and the Folivora or Tardigrada, better known as sloths (Vizcaíno et al., 2012). Mylodontidae is a member of the latter group along with three other families - Megalonychidae, Nothrotheiidae and Megatheriidae -

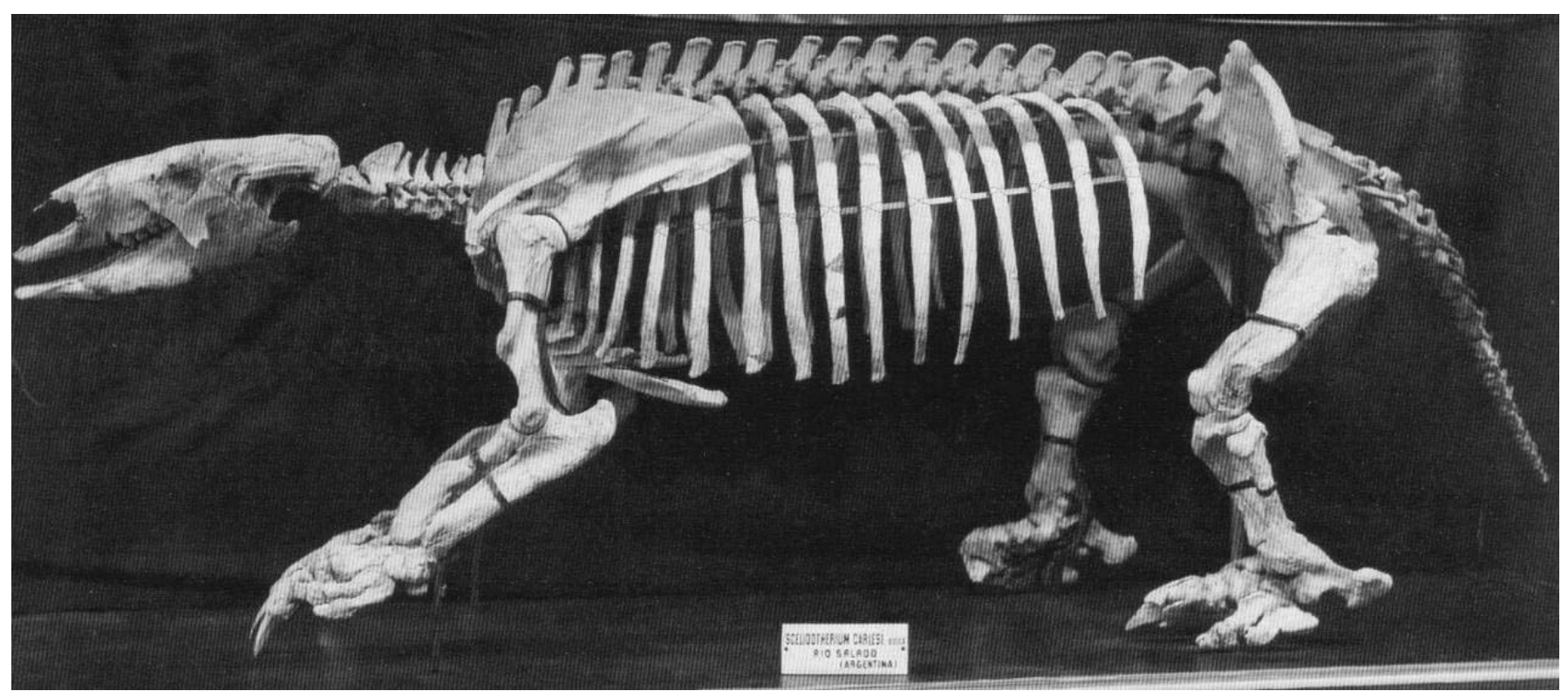

Figure 2. Mylodon (S. carlesi) from the Rodrigo Botet Collection (from Belinchón et al., 2009). 
(Fariña et al., 2013). Mylodontidae in turn is composed by two clades: Mylodontinae - the Glossotherium, Mylodon and Lestodon genera - and Scelidotheriinae the Scelidotherium, Scelidodon, Catyonyx and Valgipes genera - (Fariña et al., 2013). This family is comprised of megamammals that are over 1 tonne in body mass, although some species such as Scelidotherium leptocephalum were smaller, with an average weight of $633 \mathrm{~kg}$ (Fariña et al., 1998, 2013); in other cases, like Glossotherium robustum, some specimens weighed less than 1 tonne, which is explained by sexual dimorphism in the species (Christiansen \& Fariña, 2003; Fariña et al., 2013). This group was adapted to live in cold and dry environments, such as the Pampean Region during the Pleistocene. During this period of time savannah-grassland habitats developed, which allowed for the diversification of this family. It became extinct by the early Holocene, after a change in the climate conditions (Deschamps, 2005; Ortiz-Jaureguizar \& Cladera, 2006; Prevosti \& Vizcaíno, 2006; Miño-Boilini \& Carlini, 2009). These animals had a set of molariform, hypsodont teeth, intimately related to their different consumption habits (Paula de Couto, 1979; Fariña et al., 2013).

\section{Phylum CHORDATA Bateson, 1885 \\ Class MAMMALIA Linnaeus, 1758 \\ Order XENARTHRA Cope, 1889 \\ Family Megatheriinae Owen, 1842 \\ Genus Megatherium Cuvier, 1796}

This group, member of Tardigrada, is related to the Mylodontidae but is characterized by its enormity. In fact, the largest specimens belong to this clade, such as the well-known Megatherium americanun, which could weigh over 4 tonnes (Fig. 3). As was the case with Mylodons, this group also thrived in open spaces and was typical of the Pampean Region, although it expanded as far as the region of Ecuador, by using the Andes as a corridor as did many other species (Pujos, 2008). They developed an herbivorous diet which was probably complemented with animal protein derived from scavenging or maybe even predatory activity (Fariña, 1996; Fariña \& Blanco, 1996; Pujos, 2008). This animal was typical of the Pleistocene period and was especially abundant during the Lujanian period (Brandoni et al., 2008; Pujos, 2008).

Phylum CHORDATA Bateson, 1885

Class MAMMALIA Linnaeus, 1758

Order XENARTHRA Cope, 1889

Family Glyptodontidae Burmeister, 1879

Genus Neosclerocalyptus Paula Couto, 1957

In previous research, the provenance of the material that belonged to this family - an osteoderm - could be

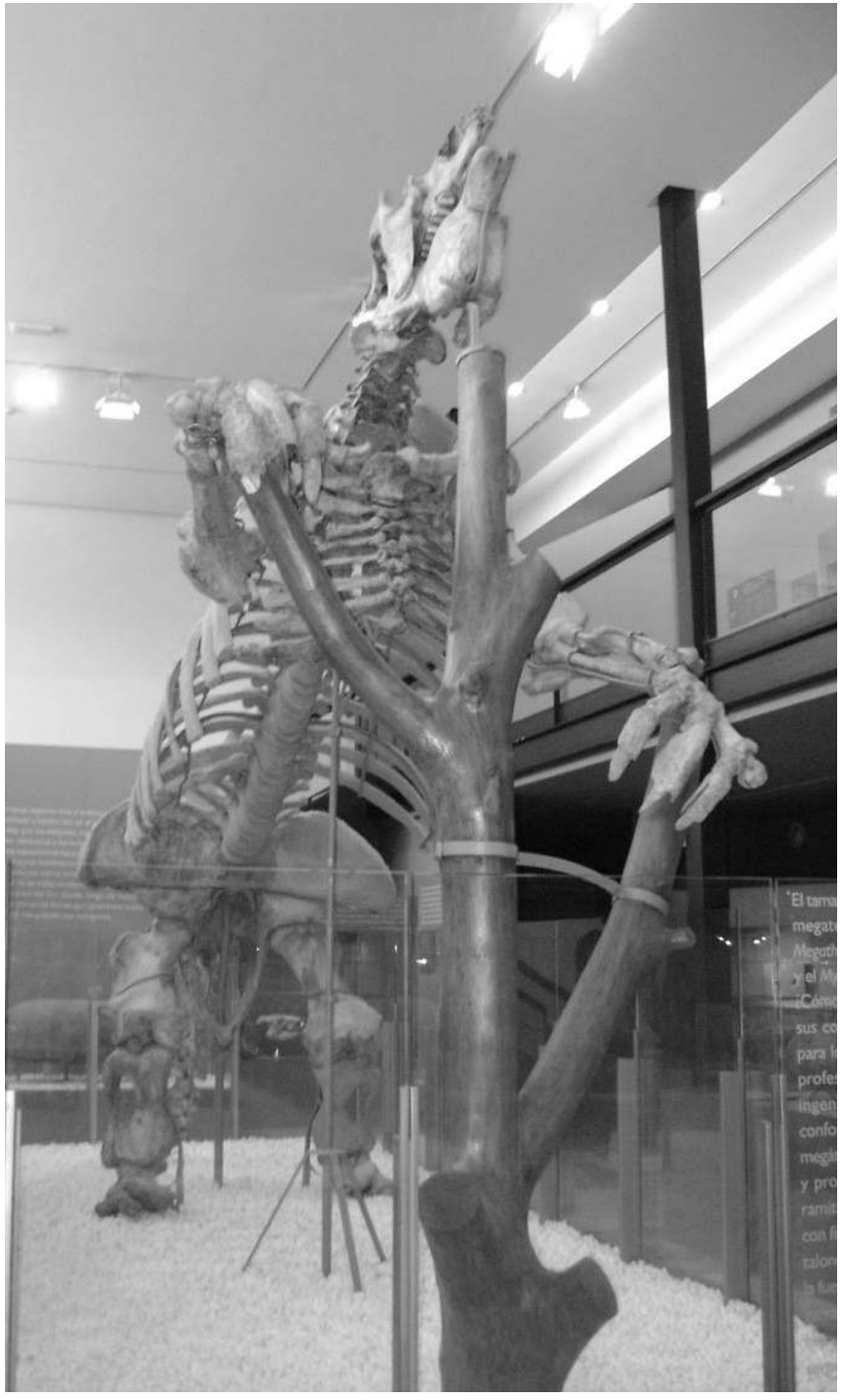

Figure 3. Megatherium americanum currently exhibited at the Natural Science Museum of Valencia (from Chichkoyan, 2011).

determined only as far as family level. In this second round of revision, we were able to identify the genus it belongs to. The families Glyptodontidae and Dasipodidae - which are the following to be explained - are part of the Cingulata. Although their general appearance differs from that of the Tardigrada, the presence of an extra joint in their vertebrae and their low basal metabolism are a characteristic feature of this order; and in addition, they are also K-selected animals when it comes to reproduction strategy (Gaudin, 1999; McDonald, 2005; Fariña et al., 2013). A remarkable feature of these animals was that they were covered with a hard shell that protected their entire body and part of their extremities. This exoskeleton was characterized by its fixed osteoderms (Fig. 4). Glyptodons also presented a merged spinal cord to support the weight of their shell (Gaudin, 1999). The Neosclerocalyptus sp., in turn belonged to the subfamily Hoplophorinae, and was 


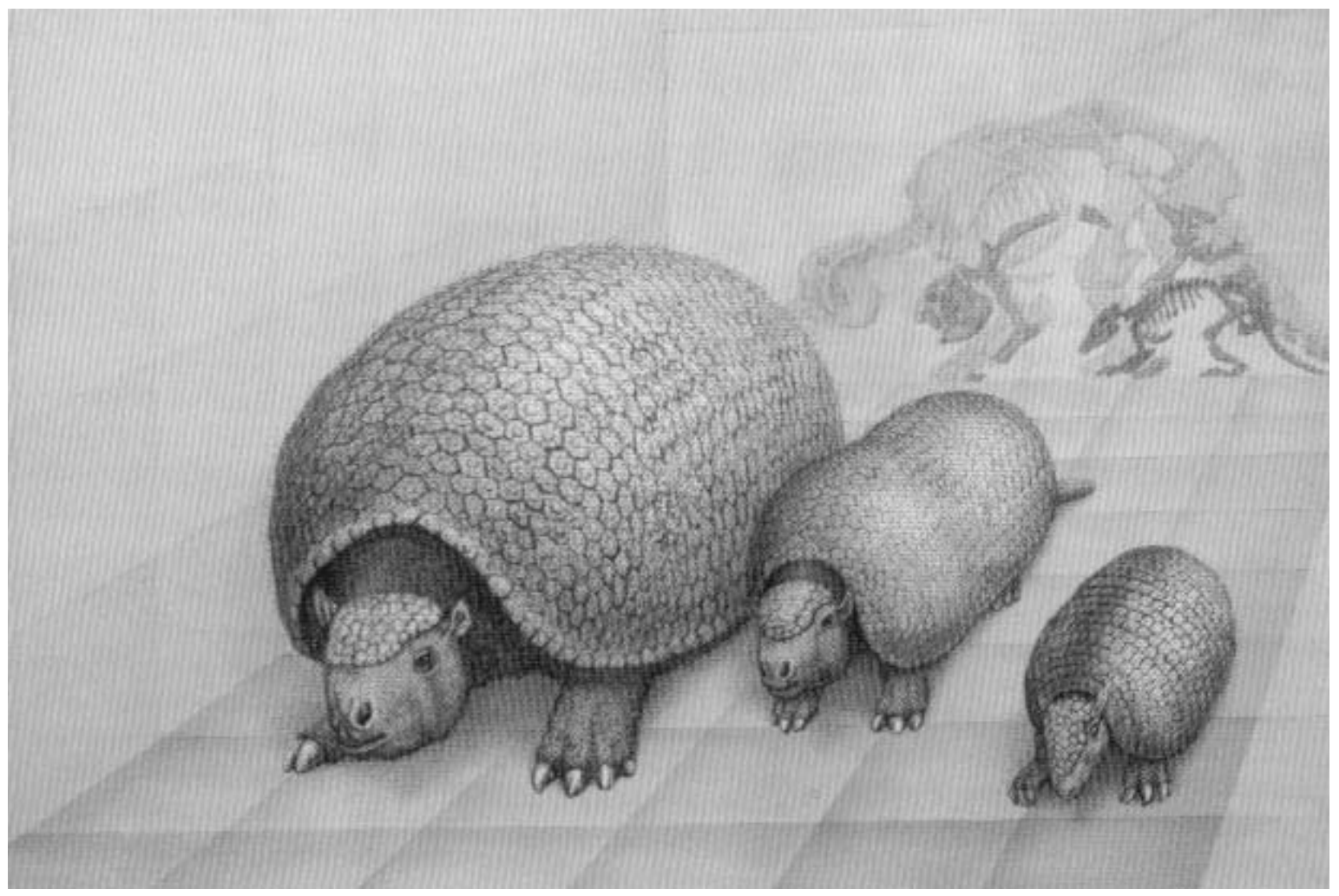

Figure 4. Several re-constructions of Cingulata, by Mauricio Antón. From left to right: Glyptodon, Neosclerocalyptus and Eutatus (from Belinchón et al., 2009).

one of the smallest species of the Family Glyptodontidae (Fariña et al., 2013). This family survived until the early Holocene and some species were part of human exploitation activities in the Pampean region, such as the Doedicurus clavicaudatus, that was excavated from La Moderna (Gutiérrez \& Martínez, 2008; Gutiérrez et al., 2010; Soibelzon et al., 2012).

\section{Phylum CHORDATA Bateson, 1885 \\ Class MAMMALIA Linnaeus, 1758 \\ Order XENARTHRA Cope, 1889 \\ Family Dasipodidae Bonaparte, 1838 \\ Genus Eutatus Gervais, 1867}

Eutatus is also a member of the Cingulata, and belonged to the Family Dasipodidae (Vizcaíno \& Bargo, 1998). These members of the group are characterized by their smaller size, $50 \mathrm{~kg}$ in body mass, and mobile osteoderms (Vizcaíno \& Bargo, 1998; Krmpotic et al., 2009; Fariña et al., 2013). In contrast with other members of this order, it is suggested that this family was characterized by an R-select reproduction strategy (McDonald, 2005). Although its body size does not qualify for it to be considered megafauna, this species belongs to the Order Xenarthra, of which there is anthropic evidence, and survived until recent times, as opposed to the rest of the megamammals, that were hardly able to survive the Pleistocene-Holocene boundary (Krmpotic et al., 2009; Gutiérrez et al., 2010) (Fig. 4).

\section{Phylum CHORDATA Bateson, 1885 \\ Class MAMMALIA Linnaeus, 1758 \\ Order LITOPTERNA Ameghino, 1889 \\ Family Machraucheniidae Gill, 1872 \\ Genus Machrauchenia Owen, 1839}

\section{Macrauchenia patachonica Owen, 1839}

Along with the Order Xenarthra, Litopterna is a group native to South America. This order was very diverse, as a result of its extensive evolution that dates back to the late Paleocene (Vizcaíno et al., 2012). Macrauchenia patachonica weighed over 1 tonne and the shape of its body was similar to that of a camel or a horse (Fariña et al., 1998, 2005) (Fig. 5). It emerged during the Ensenadan and Lujanian ages and was typical of arid climates (Bond $e t$ al., 1995). Although its size was a natural defence against predatory attacks, it has been suggested that this animal also adopted swerving and dodging strategies to avoid falling prey to predators (Fariña et al., 2005). 

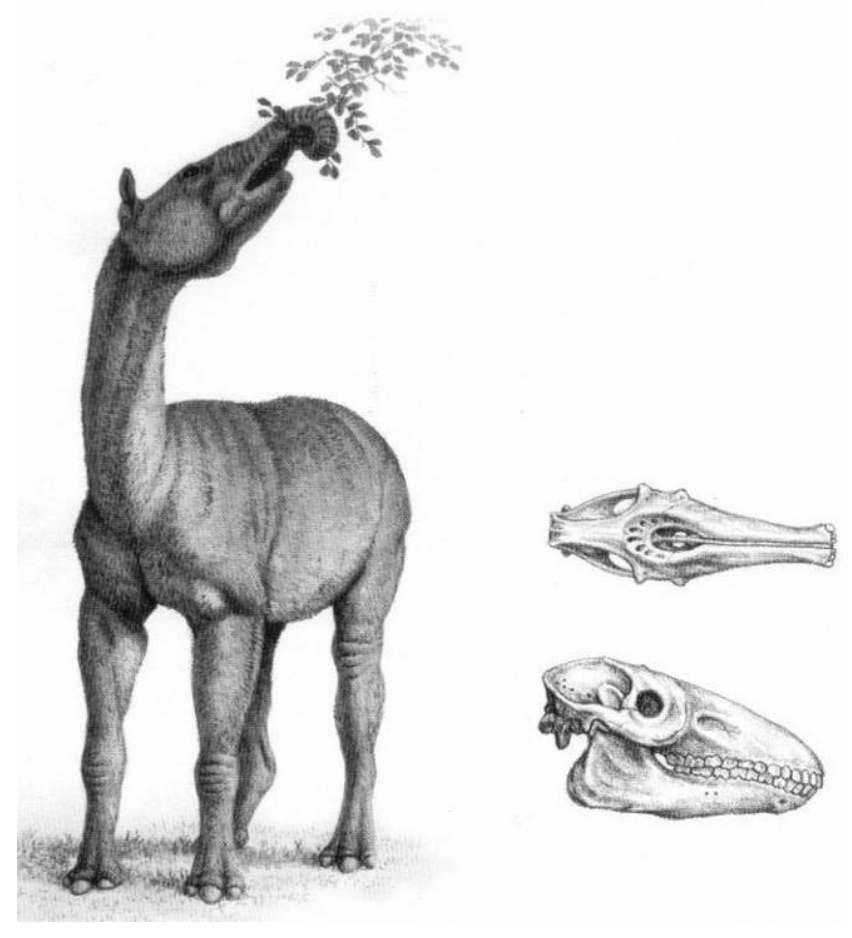

Figure 5. Macrauchenia patachonica by Mauricio Antón (from Belinchón et al., 2009).

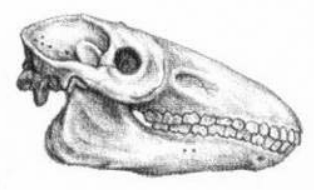

\section{RESULTS}

Ten elements from different species displayed traces of different types of anthropic action (Chichkoyan, 2011): four elements belonged to Mylodon, one rib to Megatherium sp., another two ribs to Macrauchenia patachonica and three osteoderms, one of them belonging to Neosclerocalyptus sp. and another two to Eutatus sp. Thanks to the new technologies in use, one of the bones of Macrauchenia patachonica previously reported to bear cut marks, is currently under process of study in order to determine the origin of the marks it display. The number of markings and their distribution can be viewed in Table 1 .

The diversity of the species evidencing human intervention in the collection is a very good sample of the fauna native to South America that once lived in the region and disappeared upon human arrival - with the only exception of Eutatus sp., which survived until more recent times (Chichkoyan, 2011, 2013; Chichkoyan et al., 2013). This fauna was very diverse throughout the Quaternary. The Ensenadan and Bonarean ages - during the early and middle Pleistocene - show an abundant and assorted fauna, for both extant and extinct species were detected in the biostratigraphical units. However, at the end of the Lujanian age - 130,000 to 7,000 B.P. - especially between 21,000 to 10,000 B.P., at least 52 species and 38 genera went extinct in South America: particularly, large animals and megamammals (Lessa \& Fariña, 1996; Lessa et al., 1997; Cione et al., 2009). This coincided with the rise in temperature and the wetter conditions that followed the Last Glacial Maximum - 20,000/16,000 B.P. (Rabassa et al., 2005) - which was, in general terms, essentially similar to the interglacial periods that characterized the Pleistocene.

Table 1. Material with anthropic traces found in the Rodrigo Botet Collection.

\begin{tabular}{|c|c|c|c|c|}
\hline \multirow[t]{2}{*}{ SPECIES } & \multirow[t]{2}{*}{$\begin{array}{c}\text { TYPE OF } \\
\text { BONE }\end{array}$} & \multicolumn{3}{|c|}{ SIZE (mm) } \\
\hline & & length & width & high \\
\hline Mylodontidae & Rib & 105 & 10 & 35 \\
\hline Mylodontidae & Scapula & 180 & 40 & 70 \\
\hline Mylodontidae & $\begin{array}{l}\text { Cervical } \\
\text { vertebrae }\end{array}$ & 105 & 140 & 95 \\
\hline Mylodontidae & Metatarsal & 30 & 35 & 95 \\
\hline Megatherium sp. & Rib & 1000 & 55 & 70 \\
\hline $\begin{array}{l}\text { Macrauchenia } \\
\text { patachonica }\end{array}$ & Rib & 480 & 15 & 40 \\
\hline $\begin{array}{l}\text { Macrauchenia } \\
\text { patachonica }\end{array}$ & Rib & 460 & 15 & 30 \\
\hline Neosclerocalyptus sp. & Osteoderm & 20 & 10 & 20 \\
\hline Eutatus sp. & Osteoderm & 15 & 5 & 10 \\
\hline Eutatus sp. & Osteoderm & 15 & 5 & 15 \\
\hline
\end{tabular}

With regard to the species that display anthropic action, we have noticed that out of all the groups that present anthropic cut marks, marks on the Family Mylodontidae are the most abundant in the collection; the bones bearing marks include: one rib fragment, one scapula, a fragmented cervical vertebrae and a metatarsal. The rib shows three transversal cut marks in the shaft sector; it has some manganese stains along its entire surface (Fig. 6). The scapula has one transversally oriented cut mark 11 $\mathrm{cm}$ from the glenoid cavity (Fig. 7). This element was highly affected by taphonomic agents such as roots and trampling, but the resulting imprints were left over the cut mark, indicating that the human activity occurred prior to these agents affecting the bone. The same was observed when examining the cervical vertebrae (Fig. 8), which had cut marks on its dorsal surface that were inflicted before the occurrence of trampling and manganese stains. The last of the Mylodontidae items that displayed signs of human intervention was a metatarsal (Fig. 9). Its level of preservation was quite good and the cut marks were identified on its distal epiphysis. An insect hole could also be observed in some of these marks, indicating that the cut marks happened prior to its deposition (Chichkoyan, 2011; Chichkoyan et al., 2013). The amount of cut marks in Mylodontidae bones may be related to the fact that this type of animal was the most abundantly identified in the collection $-\mathrm{N}: 1.124$ or $25,12 \%$ of the material identified. However, it could also be related to its characteristic 


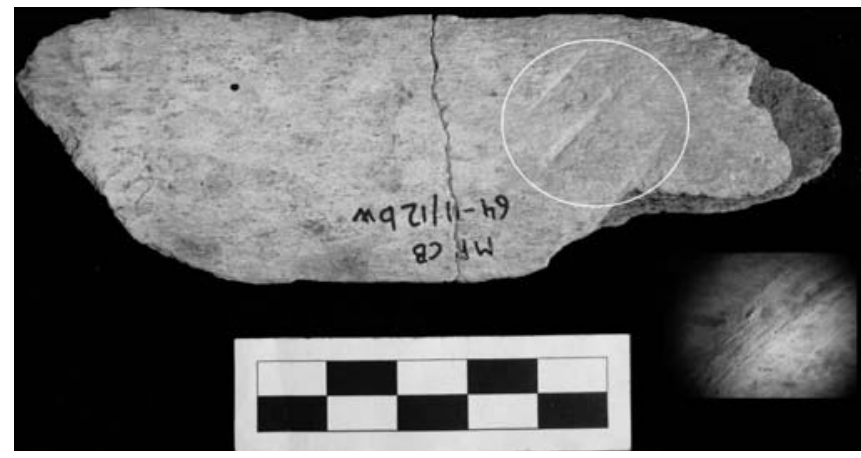

Figure 6. Mylodontidae rib with anthropic cut marks. Detail of the middle incision viewed with $40 \mathrm{X}$ magnification factor.

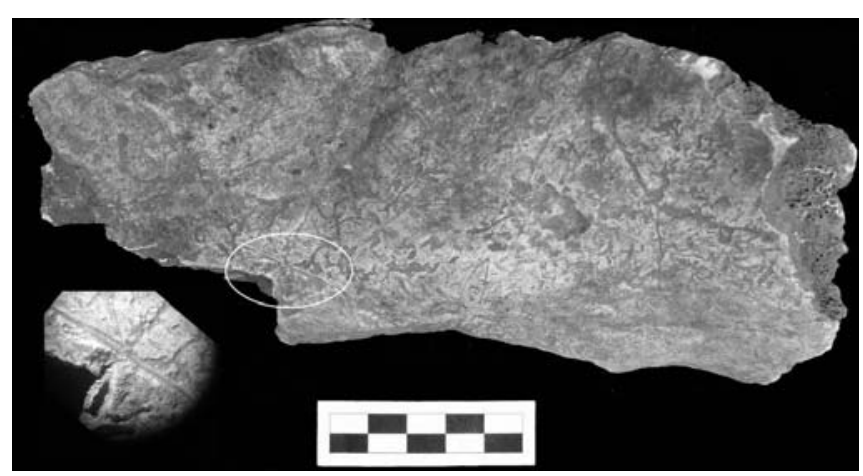

Figure 7. Mylodontidae scapulae with anthropic cut marks. Detailed view, 6.4X magnification factor.

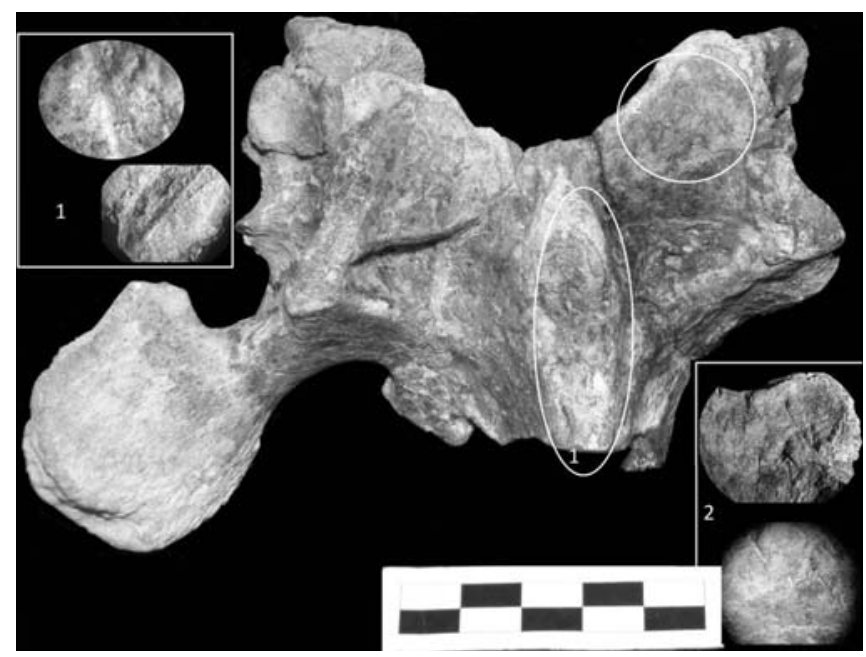

Figure 8. Mylodontidae cervical vertebrae with anthropic cut marks. The two surfaces where they were detected are shown: 1) From below: a general view of the incision. From above: Detailed view. 40X magnification factor. 2) From above: Distribution of the cut marks over the right dorsal tuberculae. From below: Detailed view, $6.4 \mathrm{X}$ magnification factor.

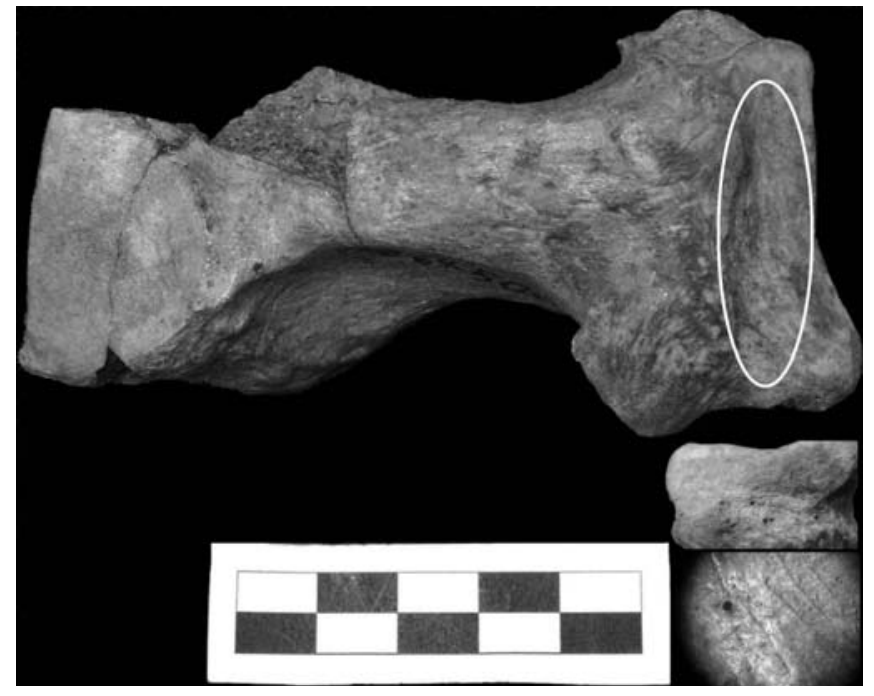

Figure 9. Mylodontidae metatarsal presenting anthropic cut marks. Close up view of the distal epiphysis and detailed view, 16X magnification factor.

distribution, since it was one of the most abundant taxa in the Pampean region, as we have mentioned previously.

Another fossil with cut marks, which also belongs to the Order Xenarthra, was a rib belonging to Megatherium sp. In this case, the first time it was studied, we detected that the bone had four cut marks in its distal sector with some original sediment still attached to part of the cut mark cavity. Three of them are in the shape of an inverted $\mathrm{N}$ and the other is spaced apart from these. This element had been weathered and is missing part of its cortical tissue; it also presents some old restoration work carried out at the museum. Other materials belonging to this order which have been subject to human activity were osteoderms of Neosclerocalyptus sp. and Eutatus. They present what may probably be anthropic polish on their sides, although one of them was also affected by fluvial erosion that rounded the item's shape. In the case of the osteoderm of Neosclerocalyptus sp., it shows trails of manganese stains along two contiguous surfaces, which would indicate that this agent developed after human intervention. In addition striations derived from polishing were also detected (Fig. 10) (Chichkoyan, 2011; Chichkoyan et al., 2013).

Finally, cut marks were identified on two ribs belonging to Macrauchenia patachonica. One set of marks were near the distal side of the rib, and the other was under the old restoration work (Fig. 11), however, given the general pattern of these markings it is possible they were the result of human intervention. The other rib that was originally presented is currently being studied.

We also observed the skeletal elements of specimens that presented anthropic action. Regarding the chances of detecting this kind of evidence, it is generally assumed that larger animals have reduced chances of tools coming 
into contact with their skeleton (Borrero, 2001; Pérez et al., 2005; Borrero \& Martín, 2012) as is the case for big mammals such as Proboscideans (Gaudzinski et al., 2005) although the authors also point out that anthropic marks can also be detected in rhinoceros. In Áridos 2, for example, a middle Pleistocene site from Spain, bones belonging to elephants were found to display cut marks (Yravedra et al., 2010). Therefore, the record of cut marks on skeletal elements is intimately related to way in which the animal was processed. In our case, most of the material corresponds to parts of the axial skeleton: four ribs and one cervical vertebrae. This could be linked to the fact that these parts are closer to the skin and a tool will more readily make contact with the bone. However, only two items of the appendicular skeleton were found to possess cut marks: the scapula and the metatarsal. The larger size of the appendicular skeleton must have hampered transporting the whole limb, and therefore, it seems more probable that only portions of meat were extracted. As a result there would be fewer marks present in these parts, and also, given the amount of muscles present, it is less probable that lithic tools would touch the bone.
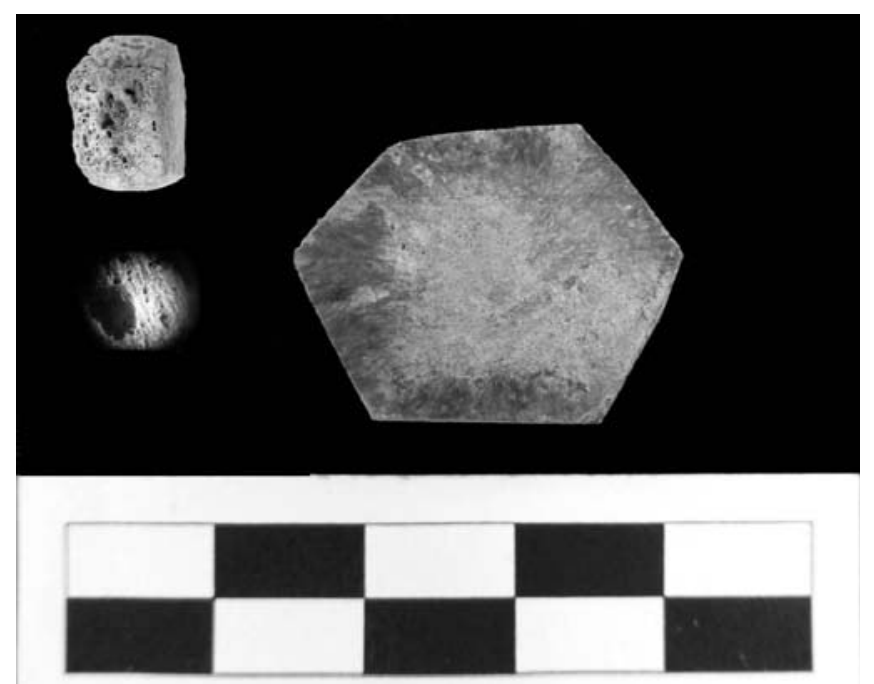

Figure 10. Glyptodontidae osteoderm. From above: detailed view of two surfaces where continuous manganese stains are visible. From below: Detailed view of the area where the parallel striations resulting from polish were detected. 40X magnification factor.

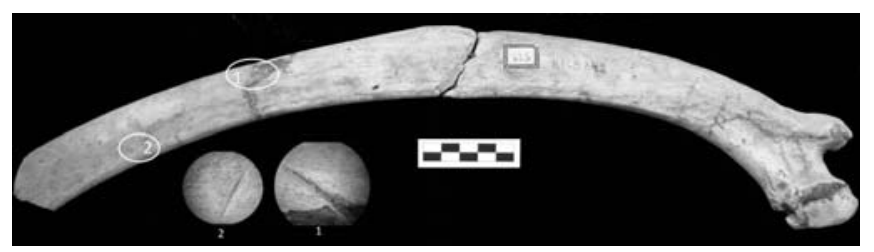

Figure 11. Rib of Macrauchenia patachonica. 1) Detailed view of the cut mark beneath the restoration work and 2) Possible cut mark on its the distal section. $40 \mathrm{X}$ magnification factor.

\section{DISCUSSION}

The cut marks on the material of the Rodrigo Botet Collection are good indication of the various large animals and megamammals that were consumed by human beings during their first dispersal in the Pampean Region. Although other animals could have well been the base of human diet, such as the Lama guanicoe (Politis et al., 2004; Cione et al., 2009), this does not imply that other species, such as the megafauna mentioned in this paper, were not consumed. There is enough evidence supporting that human beings have exploited megamammals as a natural resource in the past.

However, the possibility that human beings only scavenged meat from animals killed by other carnivores or other natural causes must still be taken into consideration, especially if we bear in mind these events happened during a moment of paleoenvironmental change. An interesting fact related to this option is that carnivores in the ecological scenario of the Pampean region had a low predatory activity (Fariña, 1996), although they may have been an important factor in other regions such as the Patagonia (Borrero \& Martín, 2012) or Chile (López Mendoza, 2007). This is consistent with fact that there were large quantities of herbivorous biomass and that Carnivora made a late arrival into the environment. The latter occurred in the late Pliocene when the two Americas were united by the Isthmus of Panama (Lessa \& Fariña, 1996; Soibelzon \& Prevosti, 2008; Woodburne, 2010). Although the imbalance hypothesis has been reassessed, and a more balanced ecological scenario has been suggested for the Pampean region, the fact remains that only Smilodon populator and eventually Panthera onca, Puma concolor and Canis nehringi were capable of predation on megammamals (Prevosti \& Vizcaíno, 2006) and it is also probable that Megatheium americanum could have had access to animal proteins, although this would have occurred as a result of its activity as an opportunistic scavenger (Fariña, 1996; Fariña \& Blanco, 1996). The size of these animals (Lessa $\&$ Fariña, 1996) rendered them inaccessible to carnivores, the same way other large animals are inaccessible to predators in other environments around the globe. Lions, however, occasionally kill large prey, such as giraffes, buffalos or rhinoceros. Regardless, for this to happen, they must hunt cooperatively given the strain of bringing large prey down (Schaller, 1972; Bertram, 1979; Hayward $\&$ Kerley, 2005). Therefore, the chances of human beings scavenging animals killed by other carnivores are reduced. It is also relevant to note that until now, no evidence of attacks by other carnivores could be found on any of the items of the collection. However, it is also important to consider that the sudden arrival of Homo sapiens could have significantly reduced the availability of prey for the native carnivores and therefore had a negative effect on their survival (Cione et al., 2009). The great capacity 
to modify their environment and adapt, plus the ability to produce weapons, rendered Homo sapiens the most formidable predator for both herbivores and carnivores alike, either directly or indirectly. However, another possibility is that humans benefitted from animals that had perished due to natural causes. Finding archaeological evidence of this is considerably more complicated since the material we studied lacks context.

Nevertheless, we may provide arguments that have been put forward to help analyse the issue. Generally speaking, it is always complicated to prove a certain animal was being hunted by human beings in the absence of direct evidence, such as a piece of lithic lodged in a bone of an animal, like the one found at Taima Taima in Venezuela (Borrero, 2009). We consider that this idea is supported by the information drawn from several stratigraphically controlled sites in the northern and southern Pampean region, which indicates human beings directly predated on megafauna. Sites such as La Moderna, Campo Laborde, Paso Otero or Cueva Tixi, in the South, have revealed that activities took place which hint towards the species Doedicurus clavicaudatus, Megatherim americanum, Equus neogeus, Hippidion sp. or Eutatus seguini being accessible to human beings. In the first of these sites, elements pertaining to Doedicurus clavicaudatus were associated with quartz tools. The animal's mandible, its axial parts, and its carapace had not been removed from the site grounds. In Campo Laborde, a rib belonging to Megatherium americanum displaying cut marks was found, and meat and viscera of the animal had seemingly been transported elsewhere, away from the carcass of the animal. In addition, the bones of megafauna had been used as fuel for kindling, for burnt bones were found at the site Paso Otero 5. In Cueva Tixi, three phalanx bones and six osteoderms belonging to Eutatus seguini had been burnt and found near what used to be a fireplace (Mazzanti \& Quintana, 1997; Politis \& Gutiérrez, 1998; Gutiérrez \& Martínez, 2008; Politis \& Messineo, 2008). Other important findings related to human-megafauna interaction have also been reported from Arroyo del Vizcaíno, Uruguay, located in the northern sector of the region. Here a non-contextualized clavicle belonging to Lestodon displayed cut marks as the result of human activity. In addition, several other bones from stratigraphically controlled excavations also presented several types of incisions (Arribas et al., 2001; Fariña, 2002; Fariña \& Castilla, 2007; Fariña et al., 2014). The anatomic positions of the cut marks on fragments of the animal's skeleton seem to indicate that human beings had direct access to different types of megamammals.

In this particular case, the information drawn from the analysis of the markings reveals that some elements are consistent with the first stages in animal processing proposed by Binford (1981). Even though this model is based on butchering procedures for medium-sized animals, the author does point out that the basic patterns of dismemberment are common for most animals since these procedures depend on the generalised anatomy of the skeleton. While the animals referred to in this work are larger in size, the general procedures for the separation of the axial and appendicular parts of the body are useful to understand how butchering of the animal could have taken place. The presence of cut marks on the cervical vertebrae, for example, is related to the process of separating the body from the skull, one of the first actions carried out during the processing of the animal (Binford, 1981). In addition, the evisceration of the carcass and skinning is also one of the first stages of the process (Binford, 1981). These actions usually cause marks on the ribs, such as those detected on several ribs of Mylodon, Macrauchenia patachonica and Megatherium sp. in the Rodrigo Botet Collection. The polishing we noticed on the osteoderms of Glyptodontidae and Eutatus is also worth discussing. This kind of activity must have been carried out on fresh material; if the osteoderm had been polished after it had fossilised, the lack of collagen in the item would have caused it to break. The rest of the material in the Rodrigo Botet Collection subject to human activity is harder to relate to any other particular stage of the processing of an animal; although the markings on the scapula belonging to Mylodontidae, since they are located close to the joint, could be attributed to the action of separating the appendicular hind limb from the rest of the body, which could also be consistent with the stages of dismemberment proposed by Binford (1981). Even though affirming that Homo sapiens had had direct access to these species of megafauna might be premature at this stage, evidence suggests that human beings were actually present from the very first stages of the process of butchering (Chichkoyan, 2011, 2013; Chichkoyan et al., 2013). Since the specimens lack any context, elucidating whether the animal was hunted or scavenged after a natural death is still complicated.

Having reached this point, it becomes relevant to relate this information to the paleoecological context of these species and the environment they inhabited. This will contextualize and aid us as we interpret the material in the Rodrigo Botet Collection in the context of different ecological settings. This information was provided by several research papers that grant us insight on how these species lived in the past. Therefore, non-contextualized cut marks can be integrated into a general framework of interaction between human beings and native fauna. Two issues are worth highlighting: on the one hand, the general ecological characteristics of the native fauna, such as their naivety in relationship with an invader species and their reproduction strategy; and on the other hand, the distribution of the species over the terrain.

Firstly, it is necessary to note that none these of species had ever come into contact with human predation previously (Cione et al., 2009). The lack of contact with an invading species contributes to the success of the invasion 
and destabilizes the established trophic chain (Kondoh, 2006). Given the relatively late arrival of our species to the continent, these species were not prepared to survive predation by the hand of a super social, technological and carnivorous primate such as Homo sapiens. The several taxa that indeed did survive the presence of human beings were those adapted to survive in areas that were not accessible to humans, such as wetlands, mountainous areas, or forests (Cione et al., 2009). The same circumstance still applies to the distribution of proboscideans nowadays that inhabit tropical forest biomes in Africa and Asia, areas where human populations hardly ever settle (Surovell et al., 2005). Other species with speedier reproductive cycles, such as guanacos (Lama guanicoe) and smaller species have been able to survive over time (Cione et al., 2009). Consequently, the lack of natural defences against a technologically superior predator such as Homo sapiens, could have favoured the decline of these slow and naive populations of megafauna.

Secondly, the rate at with which these animals became extinct varied in accordance to the speed of their sexual development and reproductive strategy (Cione et al., 2009). Megafauna, such as Megatherium sp., Mylodons, or Macrauchenia patachonica followed K-selected reproductive strategies or had low basal metabolisms, this meant they had fewer offspring per individual (Johnson, 2002; McDonald, 2005; Cione et al., 2009; Souza LimaRibeiro \& Felizola Diniz-Filho, 2013). In this sense sporadic killings of members of these species would have negatively affected birth rates for its entire population, let alone continuous depredation. Consequently, this meant several taxa would become extinct in a relatively short time period, as is the case of those species that barely passed the Pleistocene-Holocene boundary. Their situation differs from that of Eutatus, for example, which due to its great reproductive capability (McDonald, 2005) and plentiful numbers, survived until more recent times (Krmpotic et al., 2009). These circumstances also applied to other smaller mammals, such as Lama guanicoe (Cione et al., 2009). Material belonging to genus Eutatus other than that of the collection also evidence anthropic action, for example the material found in the depths of the Cueva Tixi (Mazzanti \& Quintana, 1997).

The distribution of these animals over the terrain must also be discussed and, although additional information is still required as to gain full understanding of their distribution, some insight on interesting issues has been gained this work of research and other related publications. Given the evidence collected from several Pampean sites and the evidence gathered during the analysis of the Rodrigo Botet Collection, we may suggest that the population density of these species in this region must have been higher than that of, for example, the Patagonia. Altogether, migrations, distribution, and population density must have been dependent on climatic forces, among other factors (Bennet \& Provan, 2008) and caused the differential spreading of the species. In this case, the Pampean Region, from where the Rodrigo Botet Collection originates, may have functioned as an shelter area (Bennett \& Provan, 2008) where these animals could have converged due to the cold and dry climatic conditions that prevailed throughout of the Pleistocene (Cione et al., 2009). During this period of time, climatic fluctuations influenced the expansion and dwindling of the native populations of fauna, but never caused the total extinction of taxa (Cione et al., 2009). Consequently, their numbers must have been less plentiful when Homo sapiens arrived, their population being denser in the more adequate areas for their survival. In addition to fewer species being present throughout the terrain, a new and unique, technologically superior predator such as Homo sapiens was added to the equation. Additionally, this uneven distribution may have caused heterogeneous dispersal among regions and consequently the differential access of human beings to them.

Therefore several variables influenced the development of the new palaeoecological relationships caused by the novel presence of Homo sapiens (Martínez et al., 2013). New approaches on the subject consider the arrival of Homo sapiens in America a "species invasion" (sensu Lanata et al., 2008a, b; Lanata, 2011) since they focus on the high demographic levels of human dispersal in different environments. This is related to the distribution of available resources, which must have created a hierarchy of spaces. Thus, they would have influenced the dynamics of their dispersal, resulting in "hot and cold spots" (Smith et al., 2011). Palaeoecological guidelines relate these variable resources to different scenarios of niche construction or colonization. If these modifications are persistent throughout a certain period of time, they could bring about evolutionary change during the lifespan of the species (Odling-Smee et al., 2003). In this sense, the colonization of South American environments by Homo sapiens might have been an important factor in the destabilisation of the natural adaptations that the native prehistoric fauna had developed to face the climatic oscillation typical of the Pleistocene (Cione et al., 2009; Martínez et al., 2013). This would have meant that humans had occupied, displaced, and created new positions of predation in the trophic chain, and developed new forms of niche construction or colonization. Simultaneously, this type of activity probably brought about the extinction of certain taxa both directly and indirectly (Cione et al., 2009; Martínez et al., 2013) for they altered the established palaeoecological relationships. The consequences of the invasion by Homo sapiens varied from area to area, and several factors have to be taken into account in order to fully comprehend this process. In this study, we took into consideration the distribution of the different species over the terrain, the ecological characteristics of the megafauna, such as the K-selected strategies of reproduction and their vulnerability before 
the novel presence of a highly superior predator like Homo sapiens, or the low level of competition with other carnivores. The predation on a native fauna with these characteristics would have affected the ability for survival of the population of megafaunal species and this implies new forms of niche construction.

In more general terms, the influence that human presence exerted on the prehistoric native fauna in South America can be considered part of the Sixth Great Extinction (Molina, 2008). Although this event is geologically recent and specific to mammals and megafauna (Molina, 2008; Femias Gual \& Colino Polo, 2011), it has been thoroughly studied since it is intimately related to the arrival of Homo sapiens and anthropic activity, which was highly destructive for the environment (Molina, 2008; Hortolà \& MartinezNavarro, 2012). Consequently, it is important to advance in an interdisciplinary line of research that contemplates the dispersal of Homo sapiens in different environments as a complex process and the various consequences that this must have brought about. America and Europe are excellent case studies, especially the Southern Cone of South America and the Iberian Peninsula. These are two regions characterized as being the last portion of a larger continental mass to be colonized by human beings during their initial dispersion. However, the first takes place in a latitudinal direction and is located in the Southern Hemisphere whilst the second extends in a longitudinal fashion and occurred in the Northern Hemisphere. This implies that the first arrivals of Homo sapiens in both continents occurred in a context of generalized palaeoenvironmental diversity. Ensuing work will offer information on the chronologies of the material that was presented in this paper. Other techniques for the study of the material are and will continue to be applied in order to detect cut marks and this new information will improve the results obtained so far. These will also reveal evidence in other specimens for the better understanding of the first dispersal of human beings and their impact on both continents.

\section{CONCLUSIONS}

The findings drawn from the analysis of the Rodrigo Botet Collection and their integration with a palaeocological theoretical framework support the notion that human beings colonized different geographic and palaeoecological zones during the first peopling of America. Some of them, such as the Pampean Region, would have turned into a shelter zone for the survival of megamammals throughout the Pleistocene. This would have allowed significant human predation on the native fauna, which was affected by the palaeoenvironmental changes of this period (Cione et al., 2009). Thus, the irruption of Homo sapiens in the region could have disrupted the natural state of equilibrium in the ecosystem. This can be interpreted as a phenomenon of "species invasion" (sensu Lanata et al., 2008a, b; Lanata, 2011) where, in the context of fast dispersion, several processes of niche construction or colonization would have taken place due to the new palaeoecological relationships established by the arrival of Homo sapiens.

This paper is just an example of the several interdisciplinary studies that are being conducted in order to understand the dispersal of Homo spp. in different spaces. The Southern Cone of South America is an example of how our species has altered native palaeoenvironments. In Europe, other scenarios might have occurred since the early arrival of several species of Homo spp. The final invasion of Homo sapiens - which has also been characterized as an invasive species in this palaeolandscape - must have destabilised the structural relations among these first Homo species and the rest of the populations of fauna, resulting in the loss of biodiversity and extinction of several species, including Homo neandertalensis (Hortolà \& MartinezNavarro, 2012). It is important to study in detail both continents as case studies, where different situations developed, and thereby understand the impact caused by human beings in different spaces throughout time.

\section{ACKNOWLEDGEMENTS}

This work was supported by the grants Erasmus Mundus (Master in Quaternary and Prehistory and International Doctorate in Quaternary and Prehistory) (to $\mathrm{KVCH}$ ), CGL2010 - 15326/BTE from the Spanish Ministry of Economy and Competitiveness, and 2009 SGR 324 GRC from the Generalitat de Catalunya. Special acknowledgement is due to the Natural Science Museum of Valencia that offered the material - analysed during April and May of 2010. Our special thanks to the staff of University of Ferrara (Italy), Universitat Rovira I Virgili (Spain), and IPHES, for their cooperation in the project. And also our sincere gratitude to the valuable comments by R. A. Fariña and P. Palmqvist that improved the previous version of this manuscript.

\section{REFERENCES}

Abe, Y., Marean, C.W., Nilssen, P.M., Assefa, Z. \& Stone, E.C. 2002. The Analysis of Cutmarks on Archaeofauna: A Review and Critique of Quantification Procedures, and a New Image-Analysis GIS Approach. American Antiquity, 67, 643-663.

Arribas, A., Palmqvist, P., Pérez-Claros, J.A., Castilla, R., Vizcaíno, S.F. \& Fariña, R.A. 2001. New evidence on 
the interaction between humans and megafauna in South American. Publicaciones del Seminario de Paleontología de Zaragoza, 5, 228-238.

Behrensmeyer, A.K. 1991. Terrestrial vertebrate accumulations. In: Taphonomy: releasing the data locked in the fossil record (eds. Alloson, P. \& Briggs, D.E.G.). Plenum, New York, 291-335.

Behrensmeyer, A.K. \& Kidwell, S.M. 1985. Taphonomy's contributions to Paleobiology. Paleobiology, 11, 105-119.

Belinchón, M., Peñalver, E., Montoya, P. \& Gascó, F. 2009. Crónicas de Fósiles. Las Colecciones paleontológicas del Museo de Ciencias Naturales de Valencia. Ayuntamiento de Valencia. Regidoría de Cultura, Valencia.

Bello, S.M. \& Soligo, C. 2008. A new method for the quantitative analysys of cutmark micromorphology. Journal of Archaeological Science, 35, 1542-1552.

Bello, S.M., Parfitt, S.A. \& Stringer, C. 2009. Quantitative micromorphological analyses of cut marks produced by ancient and modern handaxes. Journal of Archaeological Science, 36, 1869-1880.

Bennett, K.D. \& Provan, J. 2008. What do we mean by "refugia"? Quaternary Science Reviews, 27, 2449-2455.

Bertram, B.C. 1979. Serengeti predators and their social systems. In: Serengeti Dynamics of an ecosystem (eds. Sinclair, A.R.E \& Norton-Griffiths, M.). The University of Chicago Press, Chicago, 221-248.

Binford, L. R. 1981. Bones: Ancient Men and Modern Myths. Academic Press, New York.

Bonnichsen, R. 1989. An Introduction to Taphonomy with an Archaeological Focus. In: Bone Modification (eds. Bonnichsen, R. \& Sorg, M.). Peopling of the Americas Publications. Edited Volumen Series. Center for the Stufy of the First America, University of Maine, Maine, 1-6.

Borrero, J.L. 2001. El poblamiento de Patagonia. Toldos, milodontes y volcanes. Emecé Editores, Buenos Aires.

Borrero, L.A. 2008. Extinction of Pleistocene megamammals in South America: The lost evidence. Quaternary International, 185, 69-74.

Borrero, L.A. 2009. The Elusive Evidence: The Archaeological Record of the South American Extinct Megafauna. In: American Megafaunal Extinctions at the End of the Pleistocene (ed. Haynes, G.). Vertebrate Paleobiology and Palaeontology Series. Springer Publishers, 145-168.

Borrero, L.A. \& Martin, F.M. 2012. Ground sloths and humans in Southern Fuego-Patagonia: taphonomy and archaeology. World Archaeology, 44, 102-117.

Boscá y Casanoves, E. 1899. Noticias sobre una colección paleontológica regalada al Exmo. Ayuntamiento de Valencia. Actas de la Sociedad Española de Historia Natural, 28, 82-90.

Boscá y Casanoves, E. 1902. Nota sobre un Megaterio existente en Valencia. Boletín de la Real Sociedad de Historia Natural, 2, 139-146.

Boscá y Casanoves, E. 1917. Colección paleontológica J. Rodrigo Botet (Donada a Valencia). Restos pertenecientes al género (Scelidotherium Owen). Asociación española para el Progreso de las Ciencias. Congreso de Sevilla, p. 35-57.
Boscá y Casanoves, E. 1919. El esqueleto inédito de Eutatus punctatus AMEGHINO. Asociación española para el Progreso de las Ciencias, Sección 4. Congreso de Bilbao, p. 1-16.

Boscá y Casanoves, E. 1921. Los edentados fósiles provistos de coraza en la Colección Rodrigo Botet. Asociación española para el Progreso de las Ciencias. Congreso de Oporto, p. 125-140.

Boscá y Casanoves, E. 1923a. Notas sobre el esqueleto inédito de Machaerodus ensenadensis. AMEGHINO. Fósil de la formación pampeana. Boletín de la Real Sociedad Española de Historia Natural, 23, 182-188.

Boscá y Casanoves, E. 1923b. Los tipoteridos en la Colección de J. Rodrigo Botet, de Valencia. Asociación española para el Progreso de las Ciencias. Congreso de Salamanca, p. 29-36.

Brandoni, D., Soibelzon, E. \& Scarano, A. 2008. On Megatherium gallardoi (Mammalia, Xenarthra, Megatheriidae) and the Megatheriinae from the Ensenadan (lower to middle Pleistocene) of the Pampean Region, Argentina. Geodiversitas, 30, 793-804.

Bunn, H.T. 1991. A taphonomic perspective on the archaeology of human origin. Annual Review of Anthropology, 20, 433-467.

Catalá Gorges, J.I. 2004. El desarrollo de una carrera científica en un contexto institucional precario: el caso del naturalista Eduardo Boscá y Casanoves (1843-1924). Cronos: Cuadernos Valencianos de Historia de la Medicina y de la Ciencia, 7, 3-60.

Chichkoyan, K.V. 2011. Grandes Mamiferos del Sur: Extinciones Sudamericanas y la Colección Rodrigo Botet del Museo de Ciencias Naturales de Valencia, España. Colección Tesis. IIDyPCa-UNRN-CONICET. Bariloche. http://iidypca.homestead.com/PublicacionesIIDyPCa/ Chichkoyan/Chichkoyan.html

Chichkoyan, K.V. 2013. South American extinctions, a case study: the Rodrigo Botet Collection of the Museum of Natural Science in Valencia, Spain. Assemblage The Sheffield Graduate Journal of Archaeology, 12, 28-42.

Chichkoyan, K.V., Belinchón, M., Lanata, J.L. \& MartínezNavarro, B. 2013. La Colección Rodrigo Botet y la extinción de la megafauna en la región Del Plata (Argentina). Cuadernos del Instituto Nacional de Antropología y Pensamiento Latinoamericano, Series Especiales, 1, 48-58.

Christiansen, P. \& Fariña, R.A. 2003. Mass estimation of two fossil ground sloths (Xenarthra; Mylodontidae). In: Morphological studies in fossil and extant Xenarthra (Mammalia) (eds. Fariña, R.A, Vizcaíno, S.F \& Storch, G.). Senckenbergiana Biologica, 95-101.

Cione, A.L., Tonni, E.P. \& Soibelzon, L. 2009. Did humans cause large mammal late Pleistocene-Holocene extinction in South America in a context of shrinking open areas? In: American Megafaunal Extinctions at the End of the Pleistocene (ed. Haynes, G.). Vertebrate Paleobiology and Palaeontology Series. Springer Publishers, 125-144. 
Coard, R. 1999. One bone, two bones, wet bones, dry bones: Transport potentials under experimental conditions. Journal of Archaeological Science, 26, 1369-1375.

De Juana, S., Galán, A.B. \& Domínguez-Rodrigo, M. 2010. Taphonomic identification of cut marks made with lithic handaxes: an experimental study. Journal of Archaeological Science, 37, 1841-1850.

Deschamps, C.M. 2005. Late Cenozoic mammal biochronostratigraphy in southwestern Buenos Aires Province, Argentina. Ameghiniana, 42, 733-750.

Domínguez-Rodrigo, M., De Juana, S., Galán, A.B. \& Rodríguez, M. 2009. A new protocol to differentiate trampling marks from butchery cut marks. Journal of Archaeological Science, 36, 2643-2654.

Fariña, R.A. 1996. Trophic Relationships among Lujanian Mammals. Evolutionary Theory, 11, 125-134.

Fariña, R.A. 2002. Taphonomy and Palaeoecology of the South American giant mammals. In: Current Topics on Taphonomy and Fossilization (eds. De Renzi, M., Pardoalonso, M. V. \& Belinchón, M.). Colección Encontres, Ayuntamiento de Valencia, Valencia, 97-113.

Farina, R.A. \& Blanco, R.E. 1996. Megatherium, the stabber. Proceedings of the Royal Society Biological Science, 263 (1377), 1725-1729.

Fariña, R.A., Vizcaíno, S.F. \& Bargo, M.S. 1998. Body mass estimations in Lujanian (late Pleistocene-early Holocene of South America) mammal megafauna. Mastozoología Neotropical, 5, 87-108.

Fariña, R.A., Blanco, R.E. \& Christiansen, P. 2005. Swerving as the escape strategy of Macrauchenia patachonica (Mammalia; Litopterna). Ameghiniana, 42, 751-760.

Fariña, R.A. \& Castilla, R. 2007. Earliest evidence for humanmegafauna interaction in the Americas. In: Human and Faunal Relationships Reviewed: An Archaeozoological Approach (eds. Corona, M.E. \& Arroyo-Cabrales, J.). Archaeopress, Oxford, 31-33.

Fariña, R.A., Vizcaíno, S.F \& de Iuliis, G. 2013. Megafauna. Giant Beasts of Pleistocene South America. Bloomington. University Press, Indiana.

Fariña, R.A., Tambusso, P.S., Varela, L., Czerwonogora, A., Di Giacomo, M., Musso, M., Bracco, R. \& Gascue, A. 2014. Arroyo del Vizcaíno, Uruguay: a fosil-rich 30-ka-old megafaunal locality with cut-marked bones. Proceedings of the Royal Society Biological Science, 281: 20132211. http://dx.doi.org/10.1098/rspb.2013.2211.

Femenias Gual, J. \& Colino Polo, F. 2011. El concepto de extinción en el Cuaternario. Ab Initio, 4, 3-14.

Fernández-López, S.R. 2000. Temas de Tafonomía. Departamento de Palentología, Universidad Complutense de Madrid, Madrid.

Gaudzinski, S., Turner, E., Anzidei, A.P., Àlvarez-Fernández, E., Arroyo-Cabrales, J., Cinq-Mars, J., Dobosi, V.T., Hannus, A., Johnson, E., Müzel, S.C., Scheer, A. \& Villa, P. 2005. The use of Proboscidean remains in every-day Paleolithic life. Quaternary International, 126-128, 179-184.

Gamble, C. 2002. Arqueología Básica. Crítica, Barcelona.

Gaudin, T.J. 1999. The morphology of Xenarthrous Vertebrae (Mammalia: Xenarthra). Fieldana: Geology, 41, 1-38.
Gifford-Gonzalez, D.P. 1991. Bones are not enough: analogues, knowledge, and interpretive strategies in zooarchaeology. Journal of Anthropological Archaeology, $10,215-54$

Goetze, C. \& Mills, B. J. 1991. An assessment of the research potential of Museum collections: the Babbit Collection at the Museum of Northern Arizona. Kiva, 57, 77-91.

Gutiérrez, M.A. \& Martínez, G.A. 2008. Trends in the faunal human exploitation During the Late Pleistocene and Early Holocene in the Pampean Region (Argentina). Quaternary International, 191, 53-68.

Gutiérrez, M.A., Martínez, G.A., Bargo, M.S. \& Vizcaíno, S.F. 2010. Supervivencia diferencial de mamíferos de gran tamaño en la región pampeana en el Holoceno temprano y su relación con aspectos paleobiológicos. In: Zooarqueología a principios del siglo XXI: Aportes teóricos, metodológicos y casos de estudio (eds. Gutiérrez, M.A., De Nigris, M., Fernández, P.M., Giardina, M., Gil, A., Izeta, A., Neme, G. \& Yacobaccio, H.), Ediciones del Espinillo, Buenos Aires, 231-241.

Harding K.C., McNamara, J.M. \& Holt, R.D. 2006. Understanding invasions in pachy habitats trought metapopulation theory. In: Conceptual Ecology and Invasion Biology (eds. Cadote, M.W., McMahon, S.M. \& Fukami, T.). Springer, Netherlands, 371-404.

Hayward, M.W \& Kerley, G.I.H. 2005. Prey preferences on the lion (Panthera leo). Journal of Zoology, The Zoological Society of London, 267, 309-322.

Hortolà, P. \& Martínez-Navarro, B. 2012. The Quaternary megafaunal extinction and the fate of Neanderthals: An integrative working hypothesis. Quaternary International, 285, 69-72.

Huster, A.C. 2013. Assessing Systematic bias in Museum Collections. A case study of Spindle Whorls. Advances in Archaeological Practice: A Journal of the Society for American Archaeology, 1, 77-90.

Johnson, C.N. 2002. Determinants of loss of mammals species during the Late Quaternary "megafauna" extinctions: life history and ecology, but not body size. Proceedings of the Royal Society of London, 269, 2221-2227.

Koch, P.L. \& Barnosky, A.D. 2006. Late Quaternary Extinctions: State of the Debate. Annual Review of Ecology, Evolution, and Systematics, 37, 215-250.

Kondoh, M. 2006. Contact Experience, Alien-Native Interactions, and their community consequences: a theoretical consideration on the role of adaptation in biological invasion. In: Conceptual Ecology and Invasion Biology (eds. Cadote, M.W., McMahon, S.M. \& Fukami, T.). Springer, Netherlands, 225-242.

Krmpotic, C.M., Carlini, A.A. \& Scillato-Yané, G.J. 2009. The species of Eutatus (Mammalia, Xenarthra): Assessment, morphology and climate. Quaternary International, 210, 66-75.

Lanata, J.L., Martino, L., Osella, A. \& García-Herbst, A. 2008a. Demographic conditions necessary to colonize new spaces: the case for early human dispersal in the Americas. World Archaeology, 40, 520-537.

Lanata, J.L., Martino, L., Osella, A. \& García-Herbst, A. 2008b. Ambiente y Demografía durante la dispersión 
Humana Inicial en Sudamérica. In: Ecología Histórica: Interacciones Sociedad-Ambiente a distintas Escalas Socio-Temporales. (eds. López, C.E. \& Ospina, G.A.). Universidad Tecnológica de Pereira, Universidad del Cauca, Sociedad Colombiana de Arqueología, Pereira, 19-38.

Lanata, J.L. 2011. Discutiendo diferentes modelos de la dispersión humana en las Américas. Actas IV Simposio Internacional "El Hombre Temprano en América" (eds. Jiménez López, J.C., Serrano Sánchez, C., González González, A. \& Aguilar Arellano, F.J.). INAH, México, 121-149.

Lessa, E.P. \& Fariña, R.A. 1996. Reassessment of extinction patterns among the late Pleistocene mammals of South America. Palaeontology, 39, 651-662.

Lessa, E.P., Van Valkenburgh, B. \& Fariña, R.A. 1997. Testing hypotheses of differential mammalian extinctions subsequent to the Great American Biotic Interchange. Palaeogeography, Palaeoclimatology, Palaeoecology, 135, 157-162.

López Mendoza, P. 2007. Tafonomía de los mamíferos extintos del Pleistoceno Tardío de la costa meridional del Semiárido de Chile (IV Región-32 ${ }^{\circ}$ Latitud S). Alcances culturales y paleoecológicos. Chungara, Revista de Antropología Chilena, 39, 69-86.

Lyman, L.R. 1994. Vertebrate Taphonomy. Cambridge Manuals in Archaeology. University Press, Cambridge.

Martel San Gil, M. \& Aguirre Enríquez, E. 1964. Catálogo Inventario de la Colección Rodrigo Botet de Mamíferos Fósiles Sudamericanos del Museo Paleontológico Municipal. Ayuntamiento de Valencia, Valencia.

Martínez, G., Gutiérrez, M.A., \& Tonni, E.P. 2013. Paleoenvironments and faunal extinctions: Analysis of the archaeological assemblages at the Paso Otero locality (Argentina) during the Late Pleistocene-Early Holocene. Quaternary International, 299, 53-63.

Mazzanti, L.D. \& Quintana, C.A. 1997. Asociación cultural con fauna extinguida en el sitio arqueológico Cueva Tixi, Provincia de Buenos Aires, Argentina. Revista Española de Antropología Americana, 27, 11-21.

McDonald, H.G. 2005. Paleoecology of extinct Xenarthrans and the Great American Biotic Interchange. Bulletin of the Florida Museum of Natural History, 45, 313-333.

Miño-Boilini, A.R. \& Carlini, A.A. 2009. The Scelidotheriinae Ameghino, 1904 (Phyllophaga, Xenarthra) from the Ensenadan-Lujanian Stage/Ages (Early Pleistocene to Early-Middle Pleistocene-Early Holocene) of Argentina. Quaternary International, 210, 93-101.

Molina, E. 2008. Etapas y Causas de la Sexta Extinción en Masa. La Vida en el Terciario. Del impacto del Meteorito al Origen del Hombre. Décimas Jornadas Aragonesas de Paleontología (eds. Arcega, C. \& Lahoz, J.) Institución Fernando el Católico, Zaragoza, 187-203.

Odling-Smee, J., Laland, K.N. \& Feldman, M.W. 2003. Niche Construction: The Neglected Process in Evolution. Princeton University Press, Princeton.

Ortiz-Jaureguizar, E. \& Cladera, G. A. 2006. Paleoenvironmental evolution of Southern South America during the Cenozoic. Journal of Arid Environments, 66, 498-532.

Paula de Couto, C. 1979. Tratado de Paleomatozoologia. Academia Brasileira de Ciencias, Río de Janeiro.

Pérez de Micou, C. 1998. Las coleciones arqueológicas y la investigación. Revista do Museu de Arqueologia e Etnologia, 8, 223-233.

Pérez, R.V., Godfrey, L.R., Nowak-Kemp, M., Burney, D.A., Ratsimbazafy, J. \& Vasey, N. 2005. Evidence of early butchery of giant lemurs in Madagascar. Journal of Human Evolution, 49, 722-742.

Prevosti, F.J. \& Vizcaíno, S. 2006. Paleoecology of the large carnivore guild from the late Pleistocene of Argentina. Acta Palaeontologica Polonica, 51, 407-422.

Politis, G.G. \& Gutiérrez, M.A. 1998. Gliptodontes y Cazadores-Recolectores de la Región Pampeana (Argentina). Latin American Antiquity, 9, 111-134.

Politis G.G., Messsineo, P.G. \& Kaufmann, C.A. 2004. El poblamiento temprano de las llanuras Pampeanas de Argentina y Uruguay. Complutum, 15, 207-224.

Politis, G.G. \& Messineo, P.G. 2008. The Campo Laborde site: New Evidence for the Holocene survival of Pleistocene megafauna in the Argentine Pampas. Quaternary International, 191, 98-114.

Pujos, F. 2008 Paleogeographic distribution and anatomical adaptations in Peruvian megatheriine ground sloths (Xenarthra: Megatherioidea). In: The Biology of the Xenarthra (eds. Vizcaíno, S.F. \& Loughry, W.J.). University of Florida Press, Florida, 56-63.

Rabassa, J.A., Coronato, M., \& Salemme, M. 2005. Chronology of the late Cenozoic Patagonian glaciation and their correlation with biostratigraphic units of the Pampean region (Argentina). Journal of South American Earth Science, 20, 81-103.

Salinas Jaques, M.A. 2001. Las Colecciones Paleontológicas y Conquilógica Del Museo Paleontológico J. Rodrigo Botet de Valencia: Inventario Faunístico, Importancia Científica, Museística e Histórica. PhD Thesis, Universidad de Valencia (unpublished).

Schaller, G.B. 1972. The Serengeti lion. University of Chicago Press, Chicago.

Shipman, P. 1981. Life History of a Fossil: An Introduction to Taphonomy and Paleoecology. Harvard University Press, Cambridge.

Smith, D.L., Ericson, L. \& Burton, J.J. 2011. Co-evolutionary hot and cold spots of selective pressure move in space and time. Journal of Ecology, 99, 634-641.

Soibelzon, L.H. \& Prevosti, F.J. 2008. Los carnívoros (Carnivora, Mammalia) terrestres del Cuaternario de América del Sur. In: Geomorfologia Litoral i Quaternari. Homenatge a Joan Cuerda Barceló. (eds. Pons, G.X \& Vicens, D.). Mon. Societat D' Història Natural de les Balears, Palma de Mallorca, 49-68.

Soibelzon, L.H., Zamborano, M., Scillato- Yané, G.J., Piazza, D., Rodríguez, S., Soibelzon, E., Tonni, E.P., San Cristóbal, J. \& Beilinson, E. 2012. Un Glyptodontidae de gran tamaño en el Holoceno Temprano de la región Pampeana, Argentina. Revista Brasileira de Paleontología, 15, 105-112. 
Souza Lima-Ribeiro, M. \& Felizola Diniz-Filho, J.A. 2013. Modelos Ecológicos e a extinçao da megafauna: Clima e Homen na América do Sul. Cubo, São Carlos.

Stiner, M.C. 1994. Honor Among Thieves. A Zooarchaeological Study of Neandertal Ecology. Princeton University Press, New Jersey.

Surovell, T., Waguespack, N. \& Brantingham, J. 2005. Global archaeological evidence for proboscideans overkill. Proceedings of the National Academy of Science of the United States of America, 102, 6231-6236.

Vizcaíno, S.F. \& Bargo, M.S. 1998. The Masticatory Apparatus of the Armadillo Eutatus (Mammalia, Cingulata) and Some Allied Genera: Paleobiology and Evolution. Paleobiology, 24, 371-383.

Vizcaíno, S.F., Cassini, G.H., Toledo, N. \& Bargo, M.S. 2012. On the evolution of large size Mammalian herbivores of Cenozoic faunas of Southern South America. In: Bones, clones, and biomes: the history and geography of recent neotropical mammals (eds. Patterson, B.D. \& Costa, L.P.). The University of Chicago Press, Chicago, 76-101.

Walker, P.L \& Long, J.C. 1977. An experimental study of the morphological characteristics of tool marks. American Antiquity, 42, 605-616.
Webb, D.S. 1978. A History of Savanna Vertebrates in the New World. Part II: South America and the Great Interchange. Annual Review of Ecology and Systematics, 9, 393-426.

Wing S.L., Hans-Dieter, S., Potts, R., DiMichele, W.A. \& Behresmeyer, A.K. 1992. Evolutionary Paleoecology. In: Terrestrial Ecosystems Through Time. Evolutionary Paleoecology of Terrestrial Plants and Animal (eds. Behrensmeyer, A.K, Damuth, J.D., DiMichele, W.A., Potts, R., Sues, H.D. \& Wing, S.L.). The University of Chicago Press, Chicago \& Londres, 1-13.

Woodburne, M.C. 2010. The Great American Biotic Interchange: dispersals, tectonics, climate, sea level and holding pens. Journal of Mammal Evolution, 17, 245-264.

Yravedra, J., Domínguez-Rodrigo, M., Santoja, M., PérezGonzález, J., Panera, J., Rubio-Jara, S. \& Baquedano, E. 2010. Cut marks on the Middle Pleistocene elephant carcass of Áridos 2 (Madrid, Spain). Journal of Archaeological Science, 37, 2469-2476. 
